\title{
Use of homeopathic formula in malnourished children
}

\author{
Domitila Francisca Díaz Villanueva ${ }^{1}$, Anolys Piña Rodríguez ${ }^{1}$, \\ Lucio Ramón González García ${ }^{2}$, Carlos A. Machado Osés ${ }^{3}$
}

(1) Policlínico de San Juan de los Yeras, Villa Clara, Cuba

(2) Policlínico Universitario Juan B. Contreras, Ranchuelo, Villa Clara, Cuba

(3) Universidad "Marta Abreu" de Las Villas, Santa Clara,Villa Clara, Cuba

\begin{abstract}
The present intervention study sought to assess the results of homeopathic treatment in malnourished children aged 1-19 years old below the $3^{\text {th }}$ percentile in the weight-height ratio at San Juan Policlinic, Ranchuelo County, Cuba, between November 2004 and December 2005. A total of 99 children were randomly allocated by Mathcad in two groups, one $(n=50)$ was given homeopathic treatment, and the control group $(n=49)$ that did not. Administration of medication was defined by clinical criteria. Inclusion, exclusion and exit criteria were defined. Variables were identified and operationalized, and the information collected from both groups was interpreted. After one-year follow-up, 42 out of 50 children (84\%) treated with homeopathy attained normal weight, whereas only 15 out of $49(30 \%)$ of the children in the control group attained normal weight.
\end{abstract}

Keywords: Malnourishing; Children; Homeopathy; Comparative study

\section{Introduction}

According to the World Health Organization (WHO), about 12 million children younger than 5 years old die every year, especially in countries in development. To the WHO it is clear that children with severe malnutrition are at high risk of dying, and every year about 6 million people die from starvation [1-3].

In Cuba, nutrition and its problems also represent a source of concern [4,5]. The use of homeopathy in malnutrition is not widespread in our county. To be sure, such condition is treated with proper diet, hygiene and vitamins. However, although vitamins are useful and even indispensable in some cases, their systematic use might result in other disease, thus implying a risk for patients and economic onus for families and society at large [6-8]. On the other hand, there are no studies assessing the correlation between the nutritional state and the clinical, epidemiologic and social factors of the population $[9,10]$.

The present study sought to characterize several clinical, social and epidemiologic factors associated with malnutrition in San Juan de Years, and to assess whether homeopathic medication would help children normalize their nutritional status. For this purpose, a homeopathic complex including Calcarea fluorica 30 cH, Calcarea carbonica $30 \mathrm{cH}$ and Calcarea phosphorica $30 \mathrm{cH}$ was used. 
According to classic sources [11,12] such medications improve the assimilation of nutrients without increasing appetite. This complex has already been used in veterinary medicine $[13,14]$, but not in human beings with this particular indication.

Therefore, the aim of the present study is to assess the effectiveness of a homeopathic complex including Calc$f 30 \mathrm{cH}$, Calc $30 \mathrm{cH}$ and Calc-p $30 \mathrm{cH}$ in the treatment of malnourished children.

\section{Materials and methods}

The present exploratory intervention study was performed in San Juan de Years, Ranchuelo County, Cuba, between November 2004 and December 2005 in order to identify possible differences in the results of the treatment of malnutrition when homeopathic medication is used in addition to diet.

The sample comprised 99 malnourished [weight-height ratio was below the 3rd percentile (3P)] out of 981 children aged between 1 and 19 years old whose The sample was randomly divided in two groups by means of simple random sampling using software Mathcad 14.0. Thus, the treated group comprised 50 children, and the control group 49. No stratification was performed regarding gender and residence type (urban or rural) which, nevertheless, are described - because these factors vary in different population areas. Future studies intend to include larger samples and investigate whether such factor exert influence on the outcomes.

Inclusion criteria: low weight $(<3 \mathrm{P})$ in children aged 1 to 19 years old. Exclusion criteria: presence of encephalopathy, malformations, and severe mental retardation. Exit criteria: children who moved to other areas or did not comply with treatment.

Homeopathic treatment consisted in the use of a complex including Calc- $f 30 \mathrm{cH}$, Calc $30 \mathrm{cH}$ and Calc-p 30 $\mathrm{cH}$. Patients in both groups were prescribed a diet adjusted to their age and gender [3], and a poly-vitamins, 1 tablet/day to children older than 9 , and half tablet/day to children younger than 9 years old.

The dependent (protein-energy malnutrition) and independent (clinical, social and epidemiologic factors) variables were defined (Table 1).

Clinical assessment was based on weight-height (in $\mathrm{kg}$ and com, respectable) with inclusion, exclusion and exit criteria, and it was the determining factor to prescribe the homeopathic formula, which was given to children below $3 \mathrm{P}$.

The data were entered in an ad hoc database and data were processed first manually and then with software SPSS 15.0. Statistical analysis employed Chi-square test to establish the significance of differences between frequencies according to strata (treated and control groups) and/or time-points of a same variable (before and after use of homeopathic formula). Significance was established as: $\mathrm{p}<0.01=$ highly significant difference; $0.01 \leq \mathrm{p}<0.05=$ significant difference; and $\mathrm{p} \geq 0.05=$ non-significant difference.

\section{Results and Discussion}

The results are described in tables and graphics that allow concluding there was significant correlation between the use of homeopathic complex and attainment of normal weight in malnourished children.

Table 2 describes the initial population according to weight-eight ratio distributed in groups according to percentiles. Among 99 patients <3P, most corresponded to age-range 5 to 9 years old $(n=42,42.4 \%)$. 
Table 1. Operationalization of variables

\begin{tabular}{|c|c|c|}
\hline Variables & Description & Measurement scale \\
\hline \multicolumn{3}{|l|}{ Independent } \\
\hline \multicolumn{3}{|c|}{ Epidemiologic } \\
\hline Age & Age (years) & $\begin{array}{l}\text { Pediatric: } 4 \text { to } 19 \text { years old } \\
\text { Adults: } 20 \text { to } 64 \text { years old } \\
\text { Elderly: older than } 65 \text { years old }\end{array}$ \\
\hline Gender & Classification according to gender & $\begin{array}{l}\text { Male } \\
\text { Female }\end{array}$ \\
\hline Skin color & Definition of skin color & $\begin{array}{l}\text { White } \\
\text { Black } \\
\text { Brown } \\
\end{array}$ \\
\hline \multicolumn{3}{|l|}{ Clinical } \\
\hline Weight & Weight of patient & Kg. \\
\hline Height & Height of patient & $\mathrm{Cm}$. \\
\hline $\begin{array}{l}\text { Weight-height } \\
\text { ratio }\end{array}$ & $\begin{array}{l}\text { Ratio of weight to height in } \mathrm{kg} \text { and } \mathrm{cm} \\
\text { expressed in percentiles for the Cuban } \\
\text { population }\end{array}$ & $\begin{array}{l}\text { <3P: Malnourished. } \\
\text { 3-10 P: Thin. } \\
\text { 10-90 P: Normal weight. } \\
\text { 90-97 P: Overweight } \\
\text { >97 P: Obese }\end{array}$ \\
\hline \multicolumn{3}{|c|}{ Social } \\
\hline $\begin{array}{l}\text { Housing } \\
\text { conditions }\end{array}$ & $\begin{array}{l}\text { Good } \\
\text { Regular } \\
\text { Poor }\end{array}$ & $\begin{array}{l}\text { Good: stone or concrete flooring, sanitary service, } \\
\text { water, hygiene. } \\
\text { Regular: one of the above is lacking except for } \\
\text { hygiene. } \\
\text { Poor: as above and also hygiene lacks. }\end{array}$ \\
\hline $\begin{array}{l}\text { Parents' } \\
\text { schooling }\end{array}$ & $\begin{array}{l}\text { Elementary } \\
\text { Secondary } \\
\text { Pre-university } \\
\text { University }\end{array}$ & $\begin{array}{l}\text { Primary: completed } 6^{\text {th }} \text { grade } \\
\text { Secondary: completed } 9^{\text {th }} \text { grade } \\
\text { Pre-university: completed } 12^{\text {th }} \text { grade } \\
\text { University: attained degree. }\end{array}$ \\
\hline Overcrowding & Yes or No & Overcrowding: more than 4/room. \\
\hline $\begin{array}{l}\text { Family income } \\
\text { per capita }\end{array}$ & $\begin{array}{l}\text { Total income of the family divided by the } \\
\text { number of its members }\end{array}$ & Pesos MN (USD $1.00=$ MN \$25.00) \\
\hline $\begin{array}{l}\text { Sanitary } \\
\text { education }\end{array}$ & Mothers' knowledge on nutrition & Questionnaire \\
\hline \multicolumn{3}{|l|}{ Dependent } \\
\hline Outcomes & $\begin{array}{l}\text { Weight-height ratio before and after } \\
\text { intervention }\end{array}$ & $\begin{array}{l}\text { Solved: attained normal weight } \\
\text { Unsolved: did not attain normal weight }\end{array}$ \\
\hline
\end{tabular}


Table 2: Descriptive analysis of the study population according to weight-height ratio according to age and distributed according to percentiles

\begin{tabular}{|c|c|c|c|c|c|c|c|c|c|c|}
\hline Age & $<3 \mathrm{P}$ & $\%$ & $3-10 P$ & $\%$ & $10-90 P$ & $\%$ & $90-97 P$ & $\%$ & $>97 \mathrm{P}$ & $\%$ \\
\hline 1- 4 & 21 & 21.2 & 13 & 29.5 & 174 & 29.4 & 56 & 30.7 & 8 & 12.1 \\
\hline $5-9$ & 42 & 42.4 & 9 & 20.4 & 165 & 27.9 & 43 & 23.6 & 30 & 45.4 \\
\hline $10-14$ & 27 & 27.2 & 8 & 18.1 & 106 & 17.9 & 52 & 28.5 & 21 & 31.8 \\
\hline $15-19$ & 9 & 9 & 14 & 31.8 & 145 & 24.5 & 31 & 17 & 7 & 10.6 \\
\hline Total & 99 & 10 & 44 & 4.4 & 590 & 60.1 & 182 & 18.5 & 66 & 6.7 \\
\hline
\end{tabular}

Table 3 shows that most affected age-range was 5-9 years old (42.4\%) and that more boys (75\%) were affected compared to girls; significance varied according to age-range among highly significant (1-4 years old: $\mathrm{p}=0.001)$, significant (5-9 years old: $\mathrm{p}=0.014 ; 10-14$ years old: $\mathrm{p}=0.012)$, and non-significant (15-19 years old: $\mathrm{p}=0.096)$. The most affected age-range was $5-9$ years old $(42.4 \%)$.

Table 3: Distribution of the nutritional state according to age, gender and residence area

\begin{tabular}{|l|r|r|r|r|}
\hline \multirow{2}{*}{$\begin{array}{l}\text { Age } \\
\text { years) }\end{array}$} & \multicolumn{2}{|c|}{ Gender } & \multicolumn{2}{c|}{ Residence } \\
\cline { 2 - 5 } & Male (n, \%) & Female (n, \%) & Urban (n, \%) & Rural (n, \%) \\
\hline $\mathbf{1 - 4}$ & $18(86)$ & $3(14)$ & $5(16.6)$ & $16(23.1)$ \\
\hline $\mathbf{5 - 9}$ & $29(69)$ & $13(31)$ & $14(46.7)$ & $28(40.6)$ \\
\hline $\mathbf{1 0 - 1 4}$ & $20(74)$ & $7(26)$ & $8(26.7)$ & $19(27.6)$ \\
\hline $\mathbf{1 5 - 1 9}$ & $7(7)$ & $2(2)$ & $3(10)$ & $6(8.7)$ \\
\hline Total & $74(75)$ & $25(25)$ & $30(30)$ & $69(69)$ \\
\hline
\end{tabular}

Table 3 still shows that most malnourished children resided in the rural area, which is a historical trend due to several reasons [3,4], including deficient nutrition, poverty, lack of hygiene, dietary habits, contaminated water, and association with parasitic and bacterial diseases. Also in this case the three younger age-ranges exhibited significant difference $(p=0.016 ; p=0.031 ; p=0.034$, respectively), whereas age-range 15 - 19 years old $\operatorname{did} \operatorname{not}(\mathrm{p}=0.317)$.

Table 4 describes the age distribution of the sample population according to treatments. From 50 patients in the treated group, 10 were in the 1-4 year-old age range, 25 in the 5-9 year-old age range, 9 in the 10-14 yearold age range, and 6 in the 15-19 year-old age range. From the 49 patients in the control group, 11 were in the 1-4 year-old age range, 17 in the 5-9 year-old age range, 18 in the 10-14 year-old age range, and 3 in the 15-19 year-old age range. There were no significant differences between both groups (data not shown). 
Table 4: Distribution of the study sample per age-range and treatments

\begin{tabular}{|l|c|c|c|c|c|}
\hline \multirow{2}{*}{ Age } & \multirow{2}{*}{ Total } & \multicolumn{2}{|c|}{ Homeopathy } & \multicolumn{2}{c|}{ Control } \\
\cline { 2 - 6 } & & $\mathbf{n}$ & $\mathbf{0}$ & $\mathbf{n}$ & $\mathbf{0}$ \\
\hline $\mathbf{1 - 4}$ & 21 & 10 & 20 & 11 & 22 \\
\hline $\mathbf{5}-\mathbf{9}$ & 42 & 25 & 50 & 17 & 35 \\
\hline $\mathbf{1 0}-\mathbf{1 4}$ & 27 & 9 & 18 & 18 & 37 \\
\hline $\mathbf{1 5}-\mathbf{1 9}$ & 9 & 6 & 12 & 3 & 6 \\
\hline Total & 99 & 50 & 100 & 49 & 100 \\
\hline
\end{tabular}

Table 5 shows that 42 out of 50 (84\%) patients in the group treated with homeopathy attained normal normal weight, whereas in the control group, only 15 out of $49(30 \%)$ did, and $70 \%(n=34)$ remained below the $3^{\text {rd }}$ percentile. Distributed by age, age-range 1-4 years old proved to be the most vulnerable in the control group, since only 1 child out of $11(9 \%)$ attained normal weight.

Table 5: Distribution of the study sample per age-range and treatments after treatment

\begin{tabular}{|l|c|c|c|c|c|c|c|c|}
\hline \multirow{3}{*}{ Age } & \multicolumn{4}{|c|}{ Homeopathy } & \multicolumn{5}{c|}{ Control } \\
\cline { 2 - 9 } & Normal weight & \multicolumn{2}{|c|}{ Malnourished } & Normal weight & \multicolumn{2}{c|}{ Malnourished } \\
\cline { 2 - 9 } & $\mathbf{1 0 - 9 0} \mathbf{P}$ & $\mathbf{\%}$ & $\mathbf{7} \mathbf{~ P}$ & $\mathbf{\%}$ & $\mathbf{1 0 - 9 0} \mathbf{P}$ & $\mathbf{\%}$ & $\mathbf{7} \mathbf{P}$ & $\mathbf{\%}$ \\
\hline $\mathbf{1 - 4}$ & 9 & 18 & 1 & 2 & 1 & 2 & 10 & 21 \\
\hline $\mathbf{5 - 9}$ & 22 & 44 & 3 & 6 & 4 & 8 & 13 & 27 \\
\hline $\mathbf{1 0}-\mathbf{1 4}$ & 7 & 14 & 2 & 4 & 9 & 18 & 9 & 18 \\
\hline $\mathbf{1 5}-\mathbf{1 9}$ & 4 & 8 & 2 & 4 & 1 & 2 & 2 & 4 \\
\hline Total & 42 & 84 & 8 & 16 & 15 & 30 & 34 & 70 \\
\hline
\end{tabular}

These results show that the homeopathic treatment induced recovery of the normal weight compared to the control group. The proportion of cases that attained normal weight in the treated (42) compared to the control (15) group was statistically significant ( $<<0.001$, U test, Mathcad).

Comparison between age-ranges (Chi-square) showed that the shift to the normal weight was highly significant in age-ranges $1-4$ and 5 -9 years old ( $\mathrm{p}=0.007$ and $\mathrm{p}<0.001$, respectively), and significant in agerange 10-14 years old ( $(\mathrm{p}=0.035)$, but difference was not significant in age-range $15-19$ years old $(\mathrm{p}=0.157)$, although the trend for improvement compared to the control group is maintained.

The aims of the present study were limited to validate the effectiveness of a homeopathic formula as adjuvant in the treatment of malnutrition. Randomization was appropriate for this purpose, however, further issues must still be addressed, such as the velocity of shift from a nutritional state below the $3^{\text {rd }}$ percentile and 
normal weight and the factors able to influence such shift. In his regard, no studies could be found in the literature.

Despite such limitations and the one represented by the lack of double-blind, placebo-controlled design, these results suggest that homeopathic treatment might be efficient as adjuvant in the treatment of malnutrition and further studies with larger samples and placebo-controlled must be performed.

\section{Conclusions}

The homeopathic complex used proved to be effective as adjuvant in the treatment of malnourished children, as shown by the significant proportion of children who shifted from a condition below the $3^{\text {rd }}$ percentile to normal weight in the treated group.

This effect was highly significant and significant in age ranges 1-4, 5-9, and 10-14 years old. Although the difference was not statistically significant in age-range 15-19 years old, the trend for shift to normal was maintained compared to the control group.

\section{References}

[1] Goodmen A. Las acciones bursátiles no son comestibles [Stock exchange is not edible]. Granma, 26 de mayo de 2008: Secc. Internacionales.

[2] Amador García M, Hermelo Treche M. Alimentación y nutrición [Diet and nutrition]. In: De la Torre Montejo E, Canetin Fernández S, González Valdés J, Gutiérrez Muñiz JA, Jordán Rodríguez JR et al, Pediatría II [Pediatrics II]. La Habana: Editorial Pueblo y Educación; 2004.

[3] Martín Mateus MA, Cruz M: Inmunodeficiencias congénitas y adquiridas [Congenital and acquired immunodeficiencies]. In: Cruz M, Tratado de pediatra [Treatise of pediatrics]. $7^{\mathrm{a}}$ ed. La Habana: Editorial Ciencias Médicas; 2006.

[4] UNICEF: Cinco millones de niños africanos mueren antes de los 5 años [Five million African children die before age five years old]. Granma, 31 de mayo de 2008; Sec, Internacionales,

[5] Cruz M, Molina Font BLA, Borguño JM. Factores predisponentes en la desnutrición [Predisposing factors in malnutrition]. In: Cruz M, Tratado de pediatría [Treatise of pediatrics]. $7^{a}$ ed. La Habana: Editorial Ciencias Médicas; 2006.

[6] Melrd WC. Inseguridad alimentaria, hambre y desnutrición [Nutritional insecurity, starvation and nutrition]. In: Behrman RE, Kllegman RM, Janson HB, Nelson Tratado de Pediatría [Treatise of pediatrics]. $17^{\mathrm{a}}$ ed. Madrid: Elsevier; 2004.

[7] Herid WC. Necesidades nutricionales [Nutritional needs]. In: Bowman BA, Russell RM, Conocimientos actuales sobre nutrición [Current knowledge on nutrition], $8^{\mathrm{a}}$ ed. Washington DC: OPS; 2003.

[8] Martí-Hanneberg C. Nutrición en pediatría [Nutrition in pediatrics]. In: Cruz M, Tratado de pediatría [treatise of pediatrics]. $7^{\text {a }}$ ed. La Habana: Editorial Ciencias Médicas, 2006. 
[9] Alonso Lago O, González Hernández DI, Abreu Suárez G. Malnutrición proteico energética [Protein-energy malnutrition]. Revista Cubana de Pediatría. 2007; 79(2): 20-27,

[10] Magraner Tarrau ME, López Hernández IC, Toledo Vega C, Sandelys Acosta M, Comportamiento de la morbimortalidad infantile [Behavior of children morbimortality]. In: Pediatría, programa/resúmenes [Pediatrics/program/abstracts]. La Habana: Palacio de las Convenciones; 2005.

[11] Boericke W, Materia medica homeopática [Homeopathic materia medica]. New Delhi: B Jain [s.d.].

[12] Vannier L. Materia medica homeopática [Homeopathic materia medica]. México DF: Porrúa; 2000.

[13] Cuesta M, Soria EM. Homeopatía agropecuaria [Homeopathy in agriculture and livestock raising]. Las Villas: Samuel Feijóo; 2006.

[14] Cuesta M, Montejo E, Duvergel J, Medicina interna veterinaria II [Internal veterinary medicine II]. La Habana: Félix Varela; 2007.

\title{
Uso de fórmula homeopática em pacientes pediátricos desnutridos por defeito
}

\begin{abstract}
RESUMO
Foi realizado um estudo de intervenção com o objetivo de determinar os resultados do tratamento homeopático em crianças desnutridas por defeito com idade entre 1 e 19 anos no Policlínico San Juan, no município de Ranchuelo, em Cuba, no período dentre novembro de 2004 e dezembro de 2005 , que se achavam embaixo do $3^{\circ}$ percentil na relação peso-estatura. Um total de 99 crianças foram randomicamente divididas em dois grupos de acordo com o standard de tabelas de números aleatórios geradas no Mathcad e atribuição de números às crianças. O grupo tratado incluiu 50 crianças que receberam tratamento homeopático e o grupo controle incluiu 49 crianças que não recebera este tratamento. O critério clínico foi determinante para a aplicação do medicamente. Foram definidas as variáveis com critério de inclusão, exclusão e saída. Foram identificadas e operacionalizadas as variáveis e foi interpretada a informação colhida de ambos os grupos. Depois de um ano de acompanhamento, 42 das 50 (84\%) crianças que receberam tratamento homeopático alcançaram o peso normal, enquanto que 15 das 49 (30\%) que não receberam este tratamento alcançaram o peso normal.
\end{abstract}

Palavras-chave: Desnutrição infantil; Homeopatia; Estudo comparativo

\section{Uso de fórmula homeopática en pacientes pediátricos mal nutridos por defecto}

\section{RESUMEN}

Se realizó un estudio de intervención con el objetivo de determinar los resultados del tratamiento homeopático en niños mal nutridos por defecto en edades entre 1-19 años en el Policlínico San Juan, del municipio Ranchuelo, Cuba, en el período comprendido entre noviembre de 2004 a diciembre de 2005 , los cuales se encontraban por debajo del $3^{\circ}$ percentil de la relación peso-talla. Se conformaron dos grupos de un total 99 niños que se dividieron de forma aleatoria siguiendo el estándar de tablas de números aleatorios generadas en Mathcad y la asignación de números a los niños. Conforman el grupo estudio 50 casos con tratamiento homeopático y el grupo control lo conforman 49 casos que no lo recibieron. El criterio clínico fue determinante en la aplicación del medicamento. Se definieron las variables con criterio de inclusión, exclusión y salida. Se 
identificaron y se operacionalizaron las variables y se efectuó la interpretación de la información obtenida de los dos grupos, dando como resultado que después de un año de seguimiento de los 50 niños que recibieron tratamiento homeopático, 42 alcanzaron el peso normal (84\%) y de los 49 que no utilizó dicha medicación solo alcanzaron el peso normal un total de 15 pacientes (30\%).

Palabras clave: Desnutrición infantil; Homeopatía; Estudio comparativo

\section{(c) BY-NC-ND Licensed to GIRI}

Support: authors declare that this study received no funding

Conflict of interest: authors declare there is no conflict of interest

Received: 02 Jan 2012; Revised: 13 March 2012; Published: 31 March 2012.

Correspondence author: Lucio Ramón González García, P. Gómez 5 e/ C. Cienfuegos y M. Gómez, Ranchuelo Villa Clara Cuba. Email: luciogg@capiro.vcl.sld.cu

How to cite this article: Díaz-Villanueva DF, Piña-Rodríguez A, González-García LR, Machado-Osés CA. Use of homeopathic formula in malnourished children. Int J High Dilution Res [online]. 2012 [cited YYYY Month dd]; 11(38):2532. Available from: http://www.feg.unesp.br/ ojs/index.php/ijhdr/article/view/551/559 